\title{
El sistema de acciones reales, parte especial: la acción de precario
}

\author{
Fernando Atria Lemaitre*
}

\begin{abstract}
RESUMEN
Este artículo es parte de un proyecto mayor, que pretende defender una determinada reconstrucción del sistema de acciones reales del Código Civil. El tema de este artículo es la acción de precario, que no forma parte del sistema en su sentido original pero que ha devenido un miembro bonorario del mismo, para llenar de ese modo una laguna que el régimen de posesión inscrita deja en el sistema de acciones. Al incorporarla como parte del sistema de acciones reales, sin embargo, es necesario sujetar a la acción de precario a la disciplina propia de esas acciones. Este artículo es un intento para especificar cuál es esa disciplina. Se discuten, desde ese punto de vista, las cuestiones tradicionales que rodean la acción de precario: la carga de la prueba, qué constituye "ignorancia o mera tolerancia", qué relación hay entre la acción de precario y otras acciones, etc.
\end{abstract}

Código Civil chileno - acciones reales - propiedad - posesión - precario

The system of real actions, special part: the action of precario

\begin{abstract}
This essay belongs to a broader research project aimed at the reconstruction of the system of actiones in rem in the Chilean Civil Code. This article deals with the precario action. This action, or so it is alleged, is not part of the original, Civil Code system of actiones in rem but it has been incorporated into that system to fill a notorious gap cause by the Civil Code's system of registered possession. The transformation of the precario action into a real action, however, must subject it to the conditions of actiones in rem. This article attempts to identify those conditions and then to apply them to the precario action. In doing so, traditional issues concerning this action are discussed.
\end{abstract}

Chilean Civil Code - actiones in rem - property - possession - precario

* Doctor en Derecho, Universidad de Edimburgo. Profesor asociado de la Facultad de Derecho, Universidad de Chile. Correo electrónico: fatria@derecho.uchile.cl.

Artículo recibido el 11.3.2016 y aceptado para su publicación el 10.7.2017.

La investigación de la que este artículo es parte contó con el respaldo del Fondo Nacional de Desarrollo Científico y Tecnológico, mediante el proyecto 1130178, del que el autor es investigador principal. Agradezco la ayuda invaluable que me prestaron María Ignacia Besomi y Gonzalo Falcón, ayudantes de la Universidad de Chile. También agradezco la colaboración de Rosita Díaz y Antonia Morales, ayudantes alumnas de la Universidad Adolfo Ibáñez. 


\section{INTRODUCCIÓN: ACERCA DEL SISTEMA DE ACCIONES REALES Y LA ACCIÓN DE PRECARIO}

\section{La acción de precario en el sistema de acciones reales}

$\mathrm{E}$ n la operación real del sistema de acciones reales, la acción de precario ocupa hoy un lugar de privilegio. En algún sentido puede decirse, de hecho, que ella es la principal acción real, la que habitualmente es utilizada para dirimir litigios respecto de detentación de bienes inmuebles.

Esta situación no es parte del plan original del Código Civil. La regulación de las acciones reales contenidas en el Código Civil no hace referencia a la acción de precario, y la referencia al precario en el artículo 2195 parece ser algo casi dicho al pasar.

Es más, durante mucho tiempo no fue utilizada como una acción real. Como nos recuerda el profesor Ramón Domínguez Águila en su conocido artículo concerniente a instituciones jurisprudenciales en el Código Civil: "Hasta los años mil novecientos treinta no aparecían en las revistas de jurisprudencia nacionales, sentencias concerniente a la hoy denominada acción de precario"1. A partir de entonces la jurisprudencia fue construyendo una acción real. Poco a poco la jurisprudencia, usando únicamente de la letra del art. 2195 inc. $2^{\circ}$ permitió fundar en él una acción con caracteres semejantes a la reivindicación; pero menos exigente en sus requisitos y, por tanto, de uso más fácil y simple ${ }^{2}$.

¿Cómo es que la jurisprudencia creó a partir del texto del artículo 2195 inciso $2^{\circ}$ una acción real, que ha devenido en la acción real central? ¿Cuáles son las causas que llevaron a este singular desarrollo y cuáles sus consecuencias? Estos son los temas que pretendo discutir en este artículo. La tesis será que la acción de precario es una acción real "honoraria" en dos sentidos: el primero, el más característicamente jurídico, porque es una institución de creación judicial. Pero es también una acción real "honoraria” en el sentido no jurídico del término, ese sentido en que "honorario", dice la Real Academia, significa "Que se tiene con los honores, pero sin las responsabilidades y funciones efectivas que conlleva”. En efecto, la acción de precario ha sido creada por la jurisprudencia para solucionar un problema en el sistema de acciones reales del Código Civil, un problema grave creado por la posesión inscrita. Pero al crearla, la jurisprudencia no ha sometido a su creación a la disciplina de las acciones reales, en parte porque la doctrina no se ha preocupado de elaborar, entre nosotros, una teoría general de las acciones reales de la que pueda desprenderse lo que podríamos llamar un régimen disciplinario al que cualquier acción real deba someterse. Este artículo, que forma parte de una serie de artículos relativos al sistema de acciones reales, pretende ser una contribución a la elaboración de dicho régimen disciplinario.

\footnotetext{
${ }^{1}$ Domínguez Águila (2005). “Instituciones jurisprudenciales en el Código Civil chileno”, en Martinic y Tapia (eds.): Sesquicentenario del Código Civil de Andrés Bello (Santiago, LexisNexis), aquí p. 341.

${ }^{2}$ Ibid.
} 
El argumento completo tiene cuatro partes. La primera, relativamente conocida, pretende mostrar por qué una acción como la de precario hace falta en el sistema de acciones. Si se trata de una creación jurisprudencial, es importante entender la necesidad que guía esa creación. Luego será necesario preguntarse por qué fue la acción de precario la que se desarrolló. Algo ya he explicado en textos anteriores ${ }^{3}$, por lo que aquí será suficiente una referencia genérica. En tercer lugar habrá que mirar a la acción de precario como si fuera una acción real, y someterla entonces a las condiciones y al régimen de las acciones reales. Esta es la parte central de este texto. La cuarta parte y final explica lo que a mi juicio podría llamarse "la contradicción fundamental" del sistema de acciones complementado por la acción de precario, lo que explica que la jurisprudencia al respecto sea difícilmente sistematizable.

El intento de reconstrucción que se realiza en este y en los otros textos mencionados es un intento de reconstrucción dogmática. Todo el que conozca la jurisprudencia de la acción de precario sabe que ella no ha sido capaz de elaborar un concepto de acción real de precario. Cuando se dice que esta es una "institución jurisprudencial" no se está diciendo que mediante sucesivos fallos los tribunales han ido especificando y delimitando el modo de operación de la acción de precario como acción real, porque en esta materia es particularmente notoria la evidente incapacidad de la jurisprudencia nacional de avanzar llegando a interpretaciones dominantes que cierran vías que en algún momento estuvieron abiertas ${ }^{4}$. Solo se está diciendo que la acción de precario es utilizada como acción real en muchos casos. Esto no es una crítica a la jurisprudencia, porque en nuestra tradición jurídica no corresponde a los tribunales, sino a la doctrina, la carga de producir sistematización del derecho. Por consiguiente, la conocida irracionalidad de la jurisprudencia de precario no refleja un déficit jurisprudencial, sino académico. La jurisprudencia necesitaba llenar un vacío, y encontró la acción de precario. Es la doctrina la que ha sido incapaz de identificar en abstracto el problema que la jurisprudencia se vio forzada a resolver de ese modo y por eso no hemos avanzado mucho.

Sirva lo anterior como explicación de por qué este artículo, a pasar de referirse a una acción cuya relevancia ha sido jurisprudencialmente construida, no discute directamente sentencias judiciales. Podemos comenzar desde un segundo nivel, aprovechándonos de las sistematizaciones que ya están hechas ${ }^{5}$.

${ }^{3}$ Especialmente en Atria (2017). "Acciones reales de proteción del dominio y de mejor derecho (revindicatoria, publiciana, del art. 915)”, en Ius et Praxis, volumen $23 \mathrm{~N}^{\circ} 2$ (en prensa).

${ }^{4}$ La inexistencia de una interpretación dominante que decida las cuestiones problemáticas respecto de la acción de precario es destacada por prácticamente todos quienes se refieren a la materia. Así, entre otros, Halabí Riffo y Saffirio Suárez (1996): La Acción de Precario ante la Doctrina y la Jurisprudencia (Santiago, ConoSur), p. 1 (llamando la atención acerca de las "profundas discrepancias que se observan en nuestra jurisprudencia").

${ }^{5}$ Especialmente, ahora, el trabajo de Larroucau y Rostión (2015). “Del juicio de precario”, en Barcia (ed.) Derechos Reales (Santiago, LegalPublihsing) y el del propio Rostión (2013). El Precario en la Jurisprudencia Chilena (Santiago, LegalPublishing). Antes, véase Halabí y Saffirio, op. cit. supra, n. 4. 
Respecto de las categorías fundamentales de reconstrucción del sistema de acciones reales

\section{Las categorías del sistema de acciones reales}

El sistema de acciones del Código Civil se articula sobre la base de dos criterios: el primero distingue entre el aspecto estático y el aspecto dinámico de la propiedad y, en general, la detentación de las cosas, y el segundo entre la protección absoluta y la protección relativa del dominio y los demás derechos reales.

Las acciones que miran al aspecto estático del dominio y los derechos reales suponen que el actor reclama tener un derecho sobre la cosa. La controversia vehiculada por la acción, entonces, es una controversia sobre si el demandante tiene o no el derecho que alega tener. Las acciones que miran al aspecto dinámico del régimen de las cosas suponen la ilicitud del desplazamiento de la cosa, desde el control del demandante al del demandado. El paradigma de acción "estática” es la acción reivindicatoria, mientras el paradigma de acción "dinámica” es la querella de restablecimiento. En el primer caso la cuestión de cómo el demandante se hizo con la posesión de la cosa es irrelevante, salvo en cuanto eso sirve para mostrar que el demandante tiene o no el derecho que alega; en el segundo los derechos de las partes sobre la cosa son total y enteramente irrelevantes, y la única pregunta relevante será si el demandado se hizo con la cosa usando la violencia.

La segunda distinción, entre protección absoluta y protección relativa, tiene por finalidad evitar la desproporcionalidad y facilitar la protección de los derechos reales por la vía de no obligar a quien requiere de protección a probar más de lo que es estrictamente necesario para acceder a la protección que en concreto necesita. La acción es "absoluta" cuando el actor debe producir prueba positiva de su derecho; la acción es relativa cuando le basta probar mejor derecho que el demandado. De nuevo, la acción reivindicatoria es el paradigma de la acción "absoluta" en este sentido; el paradigma de acción "relativa” es la acción publiciana, que puede ser ejercida sin necesidad de que el que la ejerce prueba su dominio sobre la cosa, siempre que pruebe tener mejor derecho que el demandado. Veremos que es posible (y que es importante que sea posible) tener mejor derecho sin tener derecho alguno.

El sistema de acciones reales, entonces, se organiza de la siguiente manera:

1. Acciones que protegen el aspecto estático del régimen de las cosas

A. Acciones que requieren prueba absoluta del derecho:

i. la acción reivindicatoria

B. Acciones que requieren prueba relativa del derecho:

i. la acción publiciana

ii. la acción del art. 915

2. Acciones que protegen el aspecto dinámico del régimen de las cosas

i. interdictos posesorios

La anterior es una reconstrucción del sistema de acciones cuya justificación completa tendrá que esperar otra oportunidad. Lo que importa ahora es introducir la distinción 
entre protección absoluta/relativa y entre el aspecto estático/dinámico del régimen de las cosas, porque en su momento tendremos que preguntarnos dónde, en este esquema, entra la acción de precario.

Acerca de la necesidad de una acción como la de precario

\section{La acción de precario suple un déficit en el sistema de acciones reales}

La razón por la que una acción como la de precario es necesaria es que el sistema de acciones reales del Código Civil tiene una notoria laguna, que es resultado del régimen de posesión inscrita ${ }^{6}$.

La mejor manera de mostrar que se trata de un problema creado por la posesión inscrita es mostrar que, cuando se trata de bienes inmuebles no inscritos, el problema no aparece y no hay en el sistema de acciones una laguna que necesite ser colmada con algo como la acción de precario.

Al decir lo anterior no pretendo estar diciendo nada original. El punto ya ha sido observado:

Los avatares de la teoría de la posesión inscrita, que tanto han perjudicado el tráfico económico de los inmuebles en Chile, determinaban y siguen determinando, serias dificultades para enderezar la acción de dominio en contra de un mero detentador material, sin lazo contractual con el dueño. Ese ocupante no es poseedor, de estarse a los principios de esa teoría y como la acción de dominio exige que el demandado sea el "actual poseedor", la acción dirigida contra el mero detentador, conocida por un juez celoso de la teoría de la posesión inscrita, está destinada al fracaso, como frecuentemente lo resuelven los tribunales. Por otra parte, la reivindicación exige, según la tradición jurisprudencial chilena, una prueba acuciosa y completa del dominio en el demandante, según se entiende a la letra el art. 893, tarea que, dentro de nuestro sistema registral es, las más de las veces, compleja si se invoca una adquisición derivativa, de modo que la única prueba admisible resulta siendo la que proviene de considerar la prescripción adquisitiva como medio probatorio

\footnotetext{
${ }^{6}$ Lo que explica el surgimiento del precario no es la dificultad de la prueba del dominio en la acción reivindicatoria, como dicen Domínguez Hidalgo y Domínguez Benavente (1991): "Lo que la jurisprudencia se llevó", en Revista de derecho de la Universidad de Concepción (vol. 189), pp. 95-110, aquí pp. 99-100. En la acción reivindicatoria, dicen, no basta que el demandante pruebe su inscripción, debe "volver al pasado" y construir una cadena posesoria que cubra el tiempo de prescripción adquisitiva; en la de precario, por su parte, basta la inscripción. La diferencia es correcta, porque (como se explica infra, 8), cuando se ejerce la acción reivindicatoria ella se ejerce en contra de un poseedor. Y entonces el actor deberá probar el dominio directamente, no le servirá probar su posesión (que no la tiene). Por eso, el problema no está en que el actor debe probar el dominio, sino que debe demandar al poseedor.
} 
mediante el encadenamiento de títulos por el mayor tiempo que la ley haya previsto para ella ${ }^{7}$.

Consideremos entonces la situación en cuanto al régimen de acciones que se obtiene cuando se trata de un bien inmueble no sujeto al régimen inscrito. Si el que detenta materialmente la cosa es despojado con violencia, puede usar la querella de restablecimiento, y no necesitará probar nada más que la violencia del despojo. Si el despojo fue ilícito pero no violento, o si ya han pasado más de seis meses desde el despojo, todavía podrá recuperar la cosa sin probar derecho alguno sobre ella, sino solamente el hecho del despojo, su ilicitud. Para probar el despojo, por cierto, tendrá que probar que era poseedor de la cosa, pero aquí "poseedor" solo significa que detentaba la cosa a su propio nombre, con o sin derecho a ello. Nótese la lógica (dinámica) de los interdictos posesorios: el demandante no debe probar derecho sobre la cosa, solo debe probar que el desplazamiento de la cosa desde su poder al del demandando fue ilícito. El hecho de que el conflicto pueda ser decidido de este modo muestra que el derecho no reconoce en la posición del demandado ningún interés digno de protección, porque (todavía) no hay en su detentación de la cosa nada que pueda invocar a su favor: todo dependerá del modo en el que se hizo con la cosa.

Cuando la detentación que se impugna ha durado al menos un año, el que quiera recuperar la cosa ya no podrá hacerlo mostrando solamente la ilicitud del desplazamiento, porque la posesión del actual poseedor habrá alcanzado un grado de estabilidad que justifica reconocerla como un nuevo statu quo y protegerla en sus propios términos, como posesión. Ahora, para recobrar la cosa el despojado deberá probar su derecho sobre ella. Si puede, ejercerá la acción publiciana, y le bastará probar que tenía la posesión regular de la cosa y que tiene mejor derecho que el demandado ${ }^{8}$; si no puede ejercer la acción publiciana, deberá ejercer la acción más exigente: la reivindicatoria, lo que quiere decir que solo podrá recobrar la cosa si logra probar que es positivamente dueño de la cosa.

El sistema no tiene lagunas de protección: si una acción deja de estar disponible otra sigue estándolo o pasa a estarlo. Obsérvese, por ejemplo, lo que ocurre al año del despojo: los interdictos caducan, porque la situación se ha estabilizado y ya no basta probar que el demandado se hizo ilícitamente con la cosa; ahora esa detentación del demandado es reconocida como posesión y es necesario usar alguna de las otras acciones. La misma razón que hace caducar a los interdictos posesorios (la estabilización de la detentación del demandado, el reconocimiento de su posesión) deja disponible la acción reivindicatoria (o en su caso, la publiciana).

${ }^{7}$ Domínguez Águila (2005). "Instituciones jurisprudenciales”, p. 345 . El problema ha sido identificado previamente: véase Trucco (1910). "Teoría de la posesión inscrita dentro del Código Civil chileno” en Revista de Derecho y Jurisprudencia (vol. 6), pp. 131-155, aquí p. 147, quien niega que esto sea un problema para la teoría que formula; Álvarez, por su parte, cree que es un argumento decisivo en contra de la posesión inscrita: Álvarez (1928). La Inscripción no es Requisito, Garantía ni Prueba de la Posesión de los Bienes Raíces (Santiago, Imprenta y librería “Artes y Letras”), pp. 17-24.

${ }^{8}$ Para la noción de "mejor derecho", véase Atria, op. cit. supra, n. 3. 
Esto es precisamente lo que no ocurre cuando se trata de la posesión inscrita. Al cumplirse un año del momento en que el poseedor inscrito ha sido materialmente despojado de la tenencia de la cosa, el autor del despojo sigue en la misma situación que antes, detentador pero sin posesión. Y como no es poseedor no está al alcance de la acción reivindicatoria ni de la publiciana (no está al alcance de la acción del artículo 915, pero por otras razones que no pueden ser discutidas aquîî ). La conclusión es clara: después de un año del despojo, el dueño no tiene acción para recuperar su cosa (art. 920). La ironía es que la posesión inscrita pretende proteger la posesión de todo ataque material. El poseedor está tan protegido que queda desprotegido.

La pregunta, entonces, es qué acción puede usar el poseedor inscrito que ha sido materialmente despojado de la cosa cuando ya no tiene los interdictos posesorios. A esto se han ofrecido diversas respuestas: desde elegir entre diversas acciones en principio disponibles (la de precario, la del art. 915), o inventar acciones innominadas ${ }^{10}$, hasta distinguir un concepto de "posesión" para los efectos de la procedencia de la acción reivindicatoria que es distinto de la posesión para los efectos de la prescripción ${ }^{11}$. La solución principal, sin embargo, ha sido la utilización de la acción de precario. De este modo la construcción jurisprudencial ha buscado compensar el déficit de protección que deja la falta de armonía entre el régimen de la posesión inscrita y el sistema de acciones reales del Código Civil.

\section{4. ¿Por qué la acción de precario?}

Antes de continuar, es importante identificar la razón por la que fue la acción de precario elegible para desempeñar la función de complementar el sistema de acciones del modo que ya hemos indicado. No es casualidad que haya emergido del comodato, un contrato real. En los contratos reales el consentimiento juega un rol secundario, porque no es suficiente para crear el vínculo obligacional. El contrato requiere de la entrega de la cosa.

Por cierto, debido a la teoría general de los contratos en la que descansa el Código Civil (pacta sunt servanda), esa entrega es entendida como manifestación de la voluntad de las partes, de modo de poder decir que aunque el consentimiento no es suficiente para crear el vínculo obligacional los contratos reales siguen siendo contratos cuya obligatoriedad descansa en el consentimiento. Pero precisamente porque se trata de contratos en los que el consentimiento juega este rol secundario en situaciones en las que no hay consentimiento pero ha habido desplazamiento de la cosa resultan suficientemente análogas a los casos de contrato real como para que la ley los trate conjuntamente. Por eso en el caso del precario y del depósito la ley pasa naturalmente de regular una

\footnotetext{
${ }^{9}$ Porque no es "injusto retenedor": véase ibíd.

${ }^{10}$ E.g. Lathrop Gómez (2011). "Procedencia de la acción meramente declarativa del dominio en el derecho chileno" en ibíd. (vol. 17), pp. 3-24.

${ }^{11}$ Barcia (2017): "La concurrencia de acciones reales a la luz de la jurisprudencia de la Corte Suprema en torno a la posesión material”, en Revista de Derecho (Coquimbo), volumen 24 No 1 (en prensa).
} 
figura contractual (comodato, depósito) a regular una figura no contractual (depósito necesario, precario).

Cuando hay un comodato precario, el comodatario detenta una cosa ajena y el dueño puede en cualquier momento requerir la restitución; cuando hay solo precario, el precarista detenta una cosa ajena, y el dueño puede requerir en cualquier momento su restitución. Desde el punto de vista de la doctrina contractual del Código Civil (pacta sunt servanda), lo que diferencia a estas dos situaciones (que en una hay acuerdo y en la otra no) es fundamental y lo que las asemeja (una detentación de cosa ajena que no impone al dueño un deber de tolerancia) es secundario. Pero como se trata de contratos reales, lo que las diferencia es menos significativo de lo que las asemeja. Esa es la razón por la que la ley regula esta figura no contractual junto con la figura contractual respectiva ${ }^{12}$.

La diferencia entre el comodato precario y el precario se hace relevante al reconstruir el modo de operación de la acción de precario como acción real. Cuando el actor ejerce la acción comodataria, deberá probar el contrato, lo que quiere decir: debe probar la entrega. Si ejerce la acción de precario, sin embargo, el demandante parece quedar dispensado de la carga de probar la entrega, porque ya no hay contrato que probar. Parte de los problemas con los que los tribunales se han encontrado al usar la acción de precario como una acción real son reconducibles a esto. Para verlo debemos avanzar en la reconstrucción de esta acción real honoraria, la de precario.

\section{LA ACCIÓN DE PRECARIO, UNA ACCIÓN REAL HONORARIA}

\section{1. ¿Mira al aspecto estático o dinámico del régimen de las cosas?}

La acción de precario se construye a partir de la acción comodataria, la que tiene el comodante contra el comodatario. Y esa es una acción personal. Si la acción de precario ha de desempeñarse como un miembro honorario del sistema de acciones reales, entonces habrá que describir su régimen en el entendido de que es una acción real. Si es honoraria en el sentido de que es de creación judicial, debe dejar de serlo en el sentido ordinario, el de tener un estatus con los honores pero sin las responsabilidades que el estatus. Debe someterse a la disciplina de las acciones reales.

La importancia de este punto radica en que la reflexión que la doctrina ha hecho respecto de la acción de precario suele no detenerse en qué significar sujetarla a la disciplina de las acciones reales. Ignorando el sistema construido por el Código Civil y su racionalidad, la acción de precario es tratada como una acción real sin revisar su sentido

\footnotetext{
12 Para una explicación más detallada, véase Atria (2005), "Derechos reales”, en Revista de Dercho de la Universidad Adolfo Ibáñez (vol. 2), pp. 29-97, aquí pp. 31-36. En general, la doctrina está más atenta a la radical diferencia entre estas dos figuras que al hecho de que como el comodato es un contrato real esta diferencia es menos importante que lo que parece. Véase, por ejemplo, Ramos Pazos (1986), "El precario", en Revista de Derecho de la Universidad de Concepción (vol. 180), pp. 7-19, aquí p. 8.
} 
ni sus condiciones de procedencia, etc. Esto es un error, y veremos en lo que sigue que ese error tiene consecuencias.

Hemos visto que la disciplina de las acciones reales se ordena en dos dicotomías sucesivas: primero, en relación con la dimensión estática o dinámica del régimen de las cosas, y luego, tratándose de las primeras, si supone prueba absoluta o relativa del dominio.

En cuanto a la primera cuestión, el texto del inciso $2^{\circ}$ del artículo 2195 , que da la acción al "dueño", parece indicar que la acción de precario mira al aspecto estático del régimen de las cosas y exige prueba absoluta. Esto por cierto sería enteramente desproporcionado y además implicaría que la acción de precario no sirve para suplir el déficit que hemos encontrado, porque no haría más que reproducirlo.

Esto nos lleva a la segunda cuestión. Es un error asumir que si la ley dispone que la acción la tiene "el dueño" ella debe descansar en la prueba directa del dominio. Lo que determina qué tipo de acción es no es la calidad que la ley le exige al que la ejerce sino el tipo de conflicto que la acción vehicula. La acción reivindicatoria es una acción que exige prueba absoluta de domino no porque su definición (art. 889) haga referencia al dueño o porque el artículo 893 disponga que la acción corresponda "al que tiene la propiedad", sino porque se dirige contra el poseedor y nada menos que prueba absoluta de dominio es necesario para para vencer al poseedor. Por consiguiente, para determinar qué tipo de acción es la acción de precario hay que atender no a las palabras del artículo 2195, sino en contra de quien se dirige ${ }^{13}$. Esta es la segunda cuestión que debe responderse: si se trata de una acción que supone prueba absoluta del dominio o solo prueba de mejor derecho. La respuesta, de nuevo, no está en las palabras de la ley sino en la caracterización de la controversia que la acción vehicula.

Es claro que la acción de precario no puede dirigirse en contra de un poseedor, porque entonces lo que corresponde es la acción reivindicatoria. Pero ha de tratarse de alguien que "tenga" la cosa. Ahora bien, tampoco puede tratarse de un mero tenedor, porque entonces corresponden otras soluciones: si es mero tenedor de un tercero, la regla aplicable es la del artículo 896, y deberá declarar a nombre de quién detenta la cosa para que el actor pueda dirigirse en contra del poseedor, que es aquel a cuyo nombre él detenta; si es un mero tenedor del actor que no ha restituido lo que debe ser restituido, el actor tendrá la acción del contrato respectivo o la del artículo 915 (esto no puede justificarse aquí, pero la acción del art. 915, a mi juicio, es la acción que tiene el dueño de una cosa contra su antiguo mero tenedor que ha "retenido injustamente"14).

Ha de tratarse de una "tenencia", entonces, que no sea ni la mera tenencia del artículo 714 ni la posesión del artículo 700. La pregunta, por cierto, es si estas dos posibilidades agotan todas las formas de detentación.

${ }^{13}$ René Ramos sostiene que esta es una de las diferencias entre el comodato precario y el precario: "puede darse en comodato una cosa ajena. En cambio, no hay precario, no hay acción de precario, cuando la cosa es ajena", por lo que "el demandado podrá oponer la excepción de no ser dueño el demandante" (Ramos Pazos (1986), "El precario”, p. 9). Esto es correcto solo si uno no olvida que el demandante podrá probar su dominio con la sola prueba de su posesión.

${ }^{14}$ Atria, op. cit. supra, n. 3. 
En la lógica del Código, la distinción posesión/mera tenencia pretende ser una dicotomía ${ }^{15}$. Esto está explícitamente afirmado en el mensaje:

Las palabras posesión y tenencia contrastan siempre en el [Código Civil]; la posesión es a nombre propio, la tenencia a nombre ajeno.

Para que los dos términos sean una dicotomía, y "contrasten siempre”, la mera tenencia ha de ser definida negativamente. Posesión, entonces, sería "tenencia a nombre propio”, y mera tenencia sería "tenencia no a nombre propio". Aquí no hay espacio entre posesión y mera tenencia, por lo que no hay espacio para el precario.

Pero la definición del artículo 714 no es negativa, sino positiva: es "la que se ejerce sobre una cosa en lugar o a nombre del dueño”. Esto crea espacio lógico para una tercera forma de "tenencia": una que no reclama dominio propio ni reconoce dominio ajeno.

Si las dos formas de caracterizar la mera tenencia ("tenencia a nombre del dueño" y "tenencia no a nombre propio") fueran en los hechos equivalentes, el problema sería puramente terminológico. Y eso ocurre bajo el régimen posesorio del artículo 700 , porque detentar a nombre propio es lo mismo que detentar sin reconocer dominio ajeno (como queda en claro en el art. 2510 regla $3^{\mathrm{a}}$ ). Por consiguiente en términos del artículo 700 el que detenta la cosa o reconoce domino ajeno o no lo reconoce; en el primer caso es poseedor, en el segundo es mero tenedor. Lo que esto quiere decir es que la acción de precario, que supone una detentación que no es ni posesión ni mera tenencia, no tiene espacio en el régimen posesorio no inscrito.

Es el régimen de la posesión inscrita el que crea espacio para una detentación que no es ni posesión ni mera tenencia. Como dicho régimen supone una noción no fáctica de la posesión, es posible que alguien de hecho detente una cosa sin reconocer domino ajeno pero que ante la ley eso no cuente como posesión, porque no tiene inscripción. Entonces habrá que decir: no reconoce dominio ajeno, por lo que no puede ser mera tenencia, pero no es posesión, porque no tiene inscripción. Esto, por lo demás, es lo que desde el derecho romano ha caracterizado al precarista: existir en un espacio de indefinición entre la detentación a nombre propio (posesión) y a nombre ajeno (mera tenencia $)^{16}$. La acción de precario sería la acción para este caso incierto.

Como veremos, la acción de precario debe entenderse como una acción que supone prueba relativa del dominio. Sin embargo, la necesidad de usarla como una especie de acción general restitutoria en el contexto de un sistema que ignora la posesión de bienes inmuebles (o lo que es lo mismo: que llama "posesión" a la inscripción, y niega toda

${ }^{15}$ Una dicotomía es la división de una clase en dos subclases, una caracterizada por una propiedad y la otra por su negación. Por definición, entonces, la suma de ambas subclases es igual al total de la clase. Si la distinción mera tenencia/posesión fuera una dicotomía, entonces deberíamos concluir que no hay espacio para detentar una cosa sin ser lo uno o lo otro.

${ }^{16}$ Véase Moreno (1951), El Precario (Barcelona, Bosch), p. 48. Para la idea de que el "precarista" está en una relación especial con la cosa, que no puede ser descrita ni como mera tenencia ni como posesión, véase Selman (2011): "Artículo 915 del Código Civil: una solución jurisprudencial a la limitación de las acciones tradicionales", en Ius et Praxis (vol. 17), pp. 57-80, aquí pp. 67-69. Selman, sin embargo, funda esto en lo que más adelante (infra, 9.a) llamaremos la "comprensión invertida" de la exigencia de que el precario sea "sin previo contrato". 
protección jurídica a la tenencia material de la cosa con ánimo de dueño), junto con el hecho de que sus condiciones de procedencia no fueron especificadas teniendo a la vista que se convertiría en una acción real de primera importancia, han hecho que su suerte en un caso sea enteramente impredecible. Algo de esto intentaremos explicar en lo que sigue.

\section{La acción de precario y la de comodato precario}

Para comenzar el análisis, puede ser útil comparar las condiciones de la acción comodataria directa y la acción de precario, porque después de todo la segunda está construida por asimilación a la primera.

Para ejercer la acción comodataria, el comodante necesita, como en toda acción contractual, probar la existencia del contrato; probado que sea el contrato, el comodatario podrá defenderse alegando que el comodato fijaba un plazo para la restitución, que todavía no se ha cumplido, o que la cosa fue prestada para un propósito determinado, y dicho propósito todavía no se ha realizado (art. 2180). Si en el comodato no se ha pactado plazo (ni expreso ni tácito) se tratará de un precario, en el que estas alegaciones del comodatario serán improcedentes. Es decir, el comodato es precario cuando el comodatario no tiene defensa frente a la acción comodataria directa, porque lo que define al comodato precario es que justifica el uso de la cosa por el comodatario, pero no impone al dueño un deber de tolerar ese uso ${ }^{17}$.

Ya hemos observado que la introducción del precario se justifica por su analogía estructural con el comodato precario, desde el punto de vista de los contratos reales. En virtud del inciso final del artículo 2195, el dueño puede ejercer la acción no solo contra el comodatario, sino en contra de cualquiera que use su cosa en condiciones tales que él no tenga el deber de tolerar ese uso. Es decir, en contra de cualquiera que use su cosa por ignorancia o mera tolerancia suya.

¿Qué diferencia hay, desde el punto de vista del dueño, entre usar la acción comodataria directa y la acción de precario? La principal diferencia entre ambas es que solo la primera es una acción contractual. Por consiguiente, solo cuando use la acción

${ }^{17}$ La distinción entre justificar la detentación y obligar al dueño a tolerarla será relevante al intentar determinar qué significa detentar por ignorancia o mera tolerancia del dueño. Lo que importa, por cierto, no es que la detentación carezca de título en el sentido de que no tenga un antecedente jurídico que la justifique, sino que carezca de un título que obligue al demandante a tolerar el uso. Ramos dice ("El Precario", p. 12) que no procede la acción de precario si el demandado tiene un título "que por su naturaleza sea idóneo para poner la cosa en poder del demandando". Esto es un error, porque lo que importa es que el título obligue al demandante a tolerar el uso de la cosa. El error se hace evidente en el ejemplo "obvio" que cita Ramos más adelante: "es obvio que si se demanda y el demandado tiene un contrato de comodato o de arriendo que emana del mismo actor, la acción de precario no podrá prosperar por tener el demandado un título idóneo para retener la cosa" (Ramos Pazos (1986): "El precario", p. 13). Esto no es correcto. Si el demandado tiene la cosa, por ejemplo, en comodato precario, no tiene nada que oponer al dueño cuando este quiera recuperar su cosa, porque el comodato es precario precisamente cuando no impone al dueño obligación de tolerar el uso por el comodatario de la cosa. Es correcto decir que la acción de precario debe ser rechazada cuando el demandado tenga un título idóneo para retener la cosa (como, precisamente, el de arrendamiento); es incorrecto decir que siempre que el demandado tenga un título tendrá un título válido para retener. 
comodataria tendrá que probar el contrato. Al usar la acción de precario no necesitará probar el contrato, porque la acción de precario no es una acción contractual. En este caso tendrá que probar que la cosa la tiene el demandado, que es el dueño y que la tenencia de la cosa del demandado no lo obliga a él a tolerarla.

Lo primero que hay que tomar en cuenta es que la acción de precario puede ser usada en vez de la acción comodataria directa. Al hacer esto, el comodante se libera de la prueba del contrato. Recuérdese que como el comodato es un contrato real, la prueba del contrato implica la prueba de la entrega de la cosa. Si el comodante ejerce la acción de precario y no la comodataria, ya no necesitará probar la entrega, y le bastará probar que la cosa la tiene el demandado. Asimilar el precario al comodato precario es análogo a la presunción del inciso final del artículo 702, que permite probar la tradición por la vía de probar que la cosa está siendo usada por el adquirente a ciencia y paciencia de quien se obligó a entregarla: el hecho de que el demandado detente la cosa sin que el dueño tenga ningún deber de tolerar ese uso hace presumir una entrega anterior a título de comodato precario.

Este punto es importante para dilucidar una de las cuestiones que ha sido más controvertida en la jurisprudencia de la acción de precario. El artículo 2195 dispone que constituye también precario la tenencia de una cosa ajena sin previo contrato y por ignorancia o mera tolerancia del dueño. La pregunta que ha causado controversia en la jurisprudencia es: ¿Quién tiene la carga de probar que la tenencia del demandado es por ignorancia o mera tolerancia del dueño?

Una respuesta que parece plausible es la del profesor Jorge López Santa María:

Es obvio que la persona que ejerce la acción de precario debe probar que es dueño de la cosa cuya restitución solicita y, además, que ella es detentada u ocupada por la parte contraria, pero lo sensato, como ocurre en [Comunidad con Tapia y Castro con Reyes] es presumir iuris tantum la mera tolerancia del dueño, de modo que para desestimar la acción de precario sea indispensable que el demandado acredite él que existe un título o un contrato [...] incompatible con la ignorancia o mera tolerancia del dueño, referidas en el artículo 2195 in fine $e^{18}$.

Esto es tratar a la acción de precario como si fuera la misma acción comodataria directa: tratándose de esta última, el demandante debe probar la existencia del contrato que obliga al demandado, y el demandado debe probar, si es el caso, que la obligación contractual no es exigible (porque no era un comodato precario, después de todo).

Esto es correcto para una acción personal. Pero ignora lo que esto significa desde el punto de vista de lo que nos interesa aquí, que es el de la detentación de las cosas. Como el contrato de comodato es un contrato real, probar el contrato es probar la entrega de la cosa a título de comodato, y con eso probar la causa de la detentación del demandado. Como

${ }^{18}$ López (2004). "Obligaciones y contratos”, en Revista de Derecho de la Universidad Adolfo Ibáñez (vol. 1), pp. 57-84, aquí p. 61. 
el comodante ha probado que la razón por la que el demandado tiene la cosa es que la recibió de sus manos a título de comodato, corresponde ahora al demandado probar que ese comodato imponía al demandante, si ese era el caso, un deber de tolerar su uso de la cosa. En otras palabras, el demandado deberá probar, como en todo litigo contractual una vez que el contrato ha sido probado, de que no ha incumplido su obligación bajo el contrato.

Pero el inciso segundo del artículo 2195 permite al demandante demandar sin necesidad de alegar (ni, evidentemente, probar) la existencia de un contrato. Esto es el criterio de proporcionalidad operando: no se justifica exigir más cuando menos es suficiente para la protección. No se justifica exigir prueba de la entrega si probar el hecho de que el demandado tiene la cosa es suficiente. Por eso el inciso $2^{\circ}$ del artículo 2195 ahorra al demandante la dificultad de probar el hecho de la entrega, permitiéndole, como el inciso final del artículo 704, apelar directamente al resultado, al hecho de que el demandado tiene la cosa. Aplicando la lógica contractual que el profesor López Santa María aplica al precario, tendremos que decir que al demandante le bastará probar la detentación del demandado y su calidad de dueño, y le traspasará la carga de probar que su detentación es tal que el dueño tiene el deber de tolerarla.

Es este paso el que no es correcto. Porque para facilitar el ejercicio de la acción al demandante el Código lo ha eximido de la carga de probar el contrato, lo que en términos de la acción de precario implica que lo ha eximido de probar la causa de la detentación del demandado. Y sin probar la causa de la detentación del demandado no ha probado que el demandado tiene una obligación de restituir. Esto es algo importante que suele ser pasado por alto. Tratándose de las acciones reales, nunca es suficiente probar el derecho del actor. Eso es verdad incluso para la reivindicatoria, que exige que el actor pruebe que el demandado detenta a un título tal, que si el actor prueba además ser dueño su detentación será ilícita (es decir: que el demandado es poseedor); el artículo 915 carga al actor con la prueba de que se trata de un injusto retenedor, es decir, alguien que originalmente adquirió el corpus en calidad de mero tenedor suyo; la acción publiciana exige que el actor pruebe tener mejor derecho, lo que le obliga a probar la ubicación de su posesión y la del demandado en las líneas posesorias respectivas ${ }^{19}$; los interdictos implican que el querellante deberá probar la ilicitud en concreto del desplazamiento, que entonces será despojo o inminencia de despojo. Como puede verse, esto es un principio general del Código Civil: el solo hecho de que alguien sea dueño de algo no implica inmediata y directamente que cualquiera que lo tenga debe restituirlo. Pero esa es la tesis en la que descansa una posición como la que defiende el profesor López. Si la acción de precario ha de ser acogida como un miembro honorario del sistema de acciones reales, entonces debe someterse a la disciplina de las acciones reales.

El argumento anterior nos da luces para referirnos a tres cuestiones relevantes en relación con la acción de precario: la prueba del dominio, la naturaleza de la exigencia

\footnotetext{
${ }^{19}$ Para la noción de "línea posesoria", véase Atria, op. cit. supra, n. 3.
} 
de "ignorancia o mera tolerancia" y la aparente emergencia de un nuevo derecho real en la jurisprudencia de precario.

\section{LAS CONDICIONES DE PROCEDENCIA DE LA ACCIÓN DE PRECARIO}

\section{El precarista debe tener la cosa, pero no como poseedor ni mero tenedor}

Una cuestión que podría parecer extraña es la exigencia de que el actor sea dueño de la cosa. Porque esto parecería indicar que la acción de precario es más exigente que los interdictos posesorios y que la acción publiciana, que eximen al actor de probar su dominio. Pero como ya está dicho, lo que define en realidad la exigencia de una acción no es la calidad que la ley exige invocar, sino la controversia que es vehiculada por la acción.

Ya hemos explicado que la acción de precario no puede dirigirse en contra del poseedor ni en contra del mero tenedor. Por consiguiente, solo tiene sentido como acción cuando entre "poseedor" y "mero tenedor" hay una tercera posibilidad, esa que es precisamente creada por la posesión inscrita. El tema ya ha sido discutido y no es necesario volver sobre él (véase supra, 5).

\section{El actor debe probar su dominio, pero para ello bastará la prueba de posesión}

Una de las maneras en que el demandado puede defenderse de la acción es mostrando que tiene una pretensión jurídicamente reconocida de propiedad sobre la cosa, es decir, que es poseedor. Si es poseedor, la acción deberá ser rechazada. Por consiguiente, en el juicio de precario la prueba de la posesión por el actor será suficiente como prueba de dominio. Frente a quien no es poseedor, la posesión prueba el dominio. Por eso en un juicio de precario es más fácil para el actor probar la propiedad que en uno de reivindicación.

Contra esta tesis, se ha sostenido que el estándar probatorio del precario debería ser "replicado" en la acción reivindicatoria ${ }^{20}$. La demostración de que nada hay en la reivindicatoria que obligue a entender la prueba del dominio de una manera considerablemente distinta que en la acción de precario, según quienes sostienen esta tesis, está en la acción del artículo 915:

Dicho así [los autores aquí comentan una observación de Ramos, que explica que la exigencia probatoria en la reivindicatoria es superior a la del precario, porque en la reivindicatoria el demandado es poseedor y en el precario un simple detentador] bastaría con recordar la existencia del artículo $915 \ldots$ para hacer tambalear la respuesta de la interpretación clásica ${ }^{21}$.

${ }^{20}$ Larroucau y Rostión (2015), "Del juicio de precario", p. 67.

${ }^{21}$ Ibíd. La misma idea de que en cuanto a la prueba la acción de precario "se asemeja a la acción de precario, empleando ambos el mismo umbral probatorio", está en Pérez (2014). "La protección del dueño ante quien retiene indebidamente un bien: análisis jurisprudencial del artículo 915 del Código de Bello", 
Pero esto no es correcto. La acción del artículo 915 es una acción relativa de mejor derecho, no una acción absoluta como la acción reivindicatoria ${ }^{22}$. Para que proceda una acción de mejor derecho es necesario que el actor excluya otras posibles pretensiones, y por eso esta acción exige que se trate de quien inició la detentación bajo un título de mera tenencia que reconocía el domino del ahora actor. Por eso el demandante debe probar que el demandado "poseía a nombre ajeno" (es decir, era mero tenedor) y que ha "retenido indebidamente" (es decir, que no ha restituido debiendo restituir). En el caso de la acción reivindicatoria esto no ocurre, y el demandante tiene enfrente alguien que (a) tiene la cosa y (b) reclama ser dueño de ella. Eso implica que el actor deberá probar dominio sin poder recurrir al modo normal de probar el dominio, que es probar la posesión y descansar luego en la presunción del artículo 700, porque esta favorece al demandado.

Larroucau y Rostión creen que exigir en la acción reivindicatoria prueba del dominio es injustificado:

Cuando se reivindica en contra de quien posee el bien (mueble, sin lugar a dudas, aunque lo mismo es extensible a los inmuebles una vez superada la tesis original de la posesión inscrita), de lo que se beneficia el demandado es solo de una presunción. Esta presunción puede ser derrotada con antecedentes que hagan más probable la historia antagónica: que el dueño del bien no es quien lo posee, sino quien lo reivindica ${ }^{23}$.

Pero lo que "beneficia" al demandado en el juicio de reivindicación no es "solo" una presunción, que es irrelevante (la aplicación de la regla del art. 1698 llevaría a la misma conclusión). Es que él puede probar el domino del modo sencillo, probando su posesión. Esto es lo que el demandante no puede hacer, porque no tiene la posesión. El actor deberá probar su domino sin poder recurrir a su posesión no porque la ley o la doctrina se lo prohíban, sino porque esas son las condiciones en que ejerce la acción. Larroucau y Rostión protestan:

Es un exceso sostener que si el título invocado es derivativo el actor debe ofrecer una "cadena de inscripciones" que prueben que la cosa ha sido recibida de manos del anterior dueño durante, por lo menos, diez años, porque una exigencia de este tipo hace sinónimos a la prueba del dominio con la prescripción adquisitiva extraordinaria (art. 2510), de modo que, "en el fondo, el estudio de los títulos es la aplicación de los principios que gobiernan la prescripción”. La "prueba completa" del dominio hace de toda reivindicación un juicio de prescripción extraordinaria.

en Revista de derecho (Coquimbo) (vol. 21, número 1), pp. 387-421, aquí p. 405. Esto no es correcto, aunque para justificar esta afirmación es necesario analizar la acción del art. 915, lo que aquí no es posible.

${ }^{22}$ La acción del artículo 915 ha sido explicada en Atria: "Acciones reales de proteción del dominio y de mejor derecho", op. cit. supra, n3.

${ }^{23}$ Larroucau (2014), "La prueba completa del dominio en la acción reivindicatoria", en Estudios de derecho Civil IX (Santiago, LegalPublishing), aquí p. 68. 
El pasaje es difícil de entender, porque no queda claro en qué sentido lo que ellos elaboran es un argumento en contra de la posición que desean impugnar. El demandante tendrá que probar el derecho que reclama. No podrá probarlo mediante la posesión, porque no la tiene y la tiene el demandado. Tendrá, entonces, que probar que adquirió el dominio. ¿Cómo se prueba la adquisición del dominio? Probando las condiciones de operación de un modo de adquirir. Ahora bien, todos los modos de adquirir, originarios y derivativos (salvo la prescripción) tienen entre esas condiciones el dominio anterior, positiva o negativamente: la accesión supone dominio de la cosa principal, la ocupación supone que la cosa no tiene dueño. No es por necedad que la prueba del dominio ha sido llamada la probatio diabólica. En este punto hay algo muy importante que no puede ser discutido aquí, y es que en la prueba del dominio el conjunto de posiciones normativas que el derecho crea debe anclarse al mundo de los hechos. Todo esto no puede ser simplemente ignorado diciendo que para probar el dominio bastan "antecedentes que hagan más probable que el dueño del bien no es quien lo posee, sino quien lo reivindica”. Esto es verdad, pero no da ninguna pista de qué es lo que debe narrar esa "historia antagónica": lo que debe ser "más probable" es que las condiciones para adquirir el dominio son condiciones que el actor satisface.

\section{Acerca de la ignorancia o mera tolerancia}

La cuestión usual en una acción de precario es si la detentación del demandado es o no por ignorancia o mera tolerancia del dueño. Esto porque en los hechos, el caso normal de precarista no es un okupa, es decir, no es alguien que está furtivamente ocupando una cosa ajena, sino alguien que reclama derecho sobre la cosa. Ello porque, como hemos visto, la acción de precario existe en esa tierra de nadie que inesperadamente surgió entre la posesión y la mera tenencia, como consecuencia de la posesión inscrita. Esto quiere decir que la situación típica es que el precarista reclama en los hechos ser dueño de la cosa, y ese reclamo es tal si el concepto de posesión aplicable fuera el del artículo 700 (corpus y animus) sería poseedor. Pero no lo es, porque la cosa es un inmueble inscrito.

Es decir, en el caso más común, el demandado no es poseedor pese a tener corpus y animus. Lo que el demandado dirá en su defensa será, entonces, que él detenta la cosa pero no por ignorancia o mera tolerancia del dueño, sino porque tiene derecho a ocuparla. El demandante típicamente dirá que ese derecho no existe o (lo que es lo mismo) emana de actos o contratos no reconocidos por el derecho (una promesa de compraventa o una compraventa por escritura privada o consensual, por ejemplo, seguida de tradición longa manu), o que no le son oponibles, y por consiguiente que no tiene ningún deber de tolerar la tenencia del demandado.

Esto último es lo que en principio cuenta como "ignorancia o mera tolerancia": que el dueño no tiene un deber de tolerar el uso de la cosa, es decir, que el precarista no tiene un título que obligue al dueño a tolerar su uso de la cosa. "Ignorancia o mera tolerancia" es una fórmula que cubre los casos posibles en que se puede encontrar el precarista cuando el dueño no está obligado a tolerar: está en la cosa ya sin título alguno (es un okupa), ya con un título que justifica su tenencia de la cosa pero que no obliga al 
dueño a tolerarla (como el comodato precario, precisamente), por lo que su detentación es reconducible a la mera tolerancia del dueño, que teniendo derecho a hacerlo no ha exigido la restitución, o por ignorancia del dueño, que no sabía que el precarista estaba en la cosa o no sabía que la cosa era suya ${ }^{24}$.

El problema surge porque, como ya está indicado, una cosa es decir esto en el contexto de una acción comodataria, en que esta cuestión surge solo una vez que el actor ha probado que la causa de la tenencia del demandado es reconducible a su posesión (del actor), y otra es decirlo en el contexto de la acción (real) de precario. En el contexto de una acción comodataria, la exigencia de ignorancia o mera tolerancia es positiva, y se construye sobre el trasfondo de una detentación cuya causa en la entrega de la cosa por el demandante al demandado ya ha sido probada. Como el contrato que le impone la obligación de restituir ya está probado, el comodatario deberá probar que esa obligación no existe por algún hecho posterior al contrato o no es todavía exigible, lo que hará mostrando que las partes pactaron un plazo (expreso o tácito) para la restitución que todavía no ha vencido. Como consecuencia de ese plazo expreso o tácito que todavía no ha vencido, el demandante tiene el deber de tolerar su uso, y entonces la detentación del demandado es ejercicio de su derecho, no mera tolerancia del comodante (el contrato excluye que sea por ignorancia).

Este es, de hecho, el orden que siguen los artículos 2194 y 2195: el primero dispone que el comodato es precario si, positivamente, el dueño se reserva el derecho de solicitar la restitución en cualquier momento, y luego asimila al comodato precario un caso aparentemente negativo pero todavía positivo: aparentemente negativo porque no se ha pactado un plazo expreso o tácito, pero todavía positivo porque se basa en la existencia de un título que justifica la tenencia del comodatario, un título que no obliga al dueño a tolerarla. Se trata todavía de una comprensión positiva del requisito de ignorancia o mera tolerancia porque es una característica del título, que debe probarse a la manera de las obligaciones contractuales: el demandante el contrato, el demandado que no lo ha incumplido.

Pero lo que es perfectamente ordenado y adecuado tratándose de una acción contractual se hace problemático cuando esa acción pasa a ser real. Porque ahora no importa el vínculo personal entre demandante y demandado, sino la posición especial respecto de la cosa misma. Y esto permite que surja un problema que antes no podría haber surgido: ¿qué ocurre si el demandado dice ser tenedor de la cosa a nombre de un tercero?

${ }^{24}$ Una línea jurisprudencial interpreta positivamente la ignorancia o mera tolerancia, exigiendo prueba de que el demandado detenta por (a) ignorancia o (b) mera tolerancia del dueño. Pero la fórmula "ignorancia o mera tolerancia" no pretende identificar positivamente los casos en los que la acción procede, sino la de excluir el caso en el que no procede: cuando el demandado tiene un derecho que obliga al dueño. La pregunta, entonces, es si el demandado tiene derecho a detentar la cosa. Si no lo tiene, entonces diremos que está en ella por ignorancia o mera tolerancia del dueño. Nada depende que sea por una o la otra, porque "ignorancia o mera tolerancia" debe ser entendida como una categoría residual en la que queda una detención de cosa ajena cuando el dueño no tiene deber de tolerancia. Acerca de la jurisprudencia en este punto, véase Rostión (2013), El Precario, pp. 30-37. 
Nótese por qué este problema no podía alcanzar a plantearse en el juicio de comodato precario: porque para llegar a discutir el problema de si el comodato obligaba al dueño a tolerar el uso por el comodatario había que probar primer el contrato, y si el contrato ya estaba probado la posibilidad de que el demandado detentara a nombre de un tercero ya estaba excluida. Como el inciso $2^{\circ}$ del artículo 2195 exime al demandante de la prueba de la entrega, deja abierta la puerta a una comprensión de "ignorancia o mera tolerancia" en que esta ya no es la consecuencia de que exista un título que no obliga a tolerar, sino que es todo caso en que no hay un título que obligue al actor. Y esto es la causa de un problema.

Para verlo, podemos distinguir los siguientes casos: (a) el demandado recibió la cosa bajo cualquier título que (i) justifique su detentación pero (ii) no obligue al dueño a tolerarla; (b) el demandado detenta con un título no oponible al actor. Este caso tiene dos variantes: (i) el demandado es, por ejemplo, arrendatario de un tercero, y (ii) el demandando tiene un contrato con un antecesor en el título del propio demandante; (c) el demandado detenta en virtud de un vínculo que por razones formales no satisface las condiciones para justificar su tenencia (una compraventa seguida de tradición longa manu de un predio inscrito, una promesa de compraventa); y (d) el demandado es un okupa, que detenta sin título alguno.

Los casos (a) y (d) son fáciles: en el caso (a) hay un título reconducible al actor pero que no lo obliga a tolerar el uso del demandado; en el caso (d) el demandado no tiene título alguno.

Como se puede observar, la pregunta es si los casos (b) y (c) son asimilables a (a) o (d) (probablemente a d). Y aquí la cuestión decisiva es si uno aplica la lógica de las obligaciones o la de los derechos reales. Porque aplicando la lógica de las obligaciones, si lo que estamos haciendo es preguntarnos por la existencia de un deber del dueño de tolerar el uso de su cosa, entonces diremos que los casos posibles son (a) que hay un título que le permite recuperar en cualquier momento o (d) que no hay título que le obligue a tolerar. Los casos (b) y (c) caen dentro de esta segunda descripción: es claro que el demandante no es obligado a tolerar por el hecho de que el demandado tenga un contrato de arrendamiento con un tercero (efecto relativo), y los antecesores en el dominio son, contractualmente hablando, también terceros.

Pero desde la óptica de los derechos reales es evidente que, por ejemplo, el que se encuentra en el caso b(i) no puede ser asimilado al okupa del caso (d). Por eso ni el poseedor ni el mero tenedor pueden ser demandados de precario. Por consiguiente, la acción de precario solo procedería en los casos (a) y (d). De hecho, hay una jurisprudencia más estricta aún, una que lo hace proceder solo en el caso (d), sosteniendo que la acción de precario exige que no haya ningún contrato entre demandante y demandado ${ }^{25}$.

A continuación examinaremos estos casos con mayor detención ${ }^{26}$.

${ }^{25}$ Ibid.

${ }^{26}$ Las sentencias judiciales que se invocan no pretenden ser estadísticamente representativas, pero ilustran adecuadamente los casos más comunes de precario. Ellas han sido tomadas de las sentencias comentadas 
(a) El demandado recibió la cosa en comodato precario o en virtud de un contrato o acuerdo anterior

Este caso es en términos de la regla del inciso $2^{\circ}$ del artículo 2195 un caso indiscutible de procedencia de la acción de precario, porque ella no exige la ausencia de contrato, sino permite ejercer la acción de precario sin contrato. En otras palabras, el hecho de que el demandado detente la cosa porque el demandante se la entregó no justifica rechazar la acción por faltar el requisito de "sin previo contrato". Por eso la conjunción de ignorancia o mera tolerancia como causa de la prolongación de la tenencia: ignorancia si la tenencia del demandando no es reconducible al acuerdo del demandante, mera tolerancia si es reconducible. El hecho de que la ignorancia se asimile a la mera tolerancia muestra que la ley no exige que no haya contrato, sino admite la acción incluso en el caso de que no haya contrato.

Todo lo anterior es obvio, pero ya hemos mencionado que a veces la jurisprudencia ha invertido las cosas sosteniendo que es un requisito de procedencia del precario que la detentación no sea reconducible a un contrato anterior. Esta posición, aunque es claramente incorrecta, no puede ser descartada sin más. Es una manera de contener, e intentar modular, los efectos radicales de la acción de precario desplegada como no estaba previsto que fuera desplegada, como acción real. Es un intento no muy depurado de someter la acción de precario a la disciplina de las acciones reales. No muy depurado, porque la doctrina no ha notado la necesidad de elaborar el régimen de las acciones reales. Lo que aparece ante el juez es lo inadecuado de acoger la acción cuando hay una relación contractual en el trasfondo, por lo que el juez busca una manera de evitarlo. La jurisprudencia sin un momento doctrinario de reconstrucción racional no puede ser más que decisión caso a caso.

El caso es el siguiente: el demandado ha probado que detenta no como okupa sino porque su detentación fue pactada con el dueño, en el contexto de una relación que excede a la detentación de la cosa. Por esta razón, en la medida en que ese pacto no cree una obligación oponible al dueño de tolerar el uso de la cosa, no debería ser óbice para la procedencia de la acción de precario, pero muchas veces las cosas no son tan claras. Eso por supuesto no implica que el demandado tenga derecho. Pero sí implica que se trata de situaciones que no pueden ser discutidas en el contexto de una acción de precario, que es especialmente sumaria y que restringe notoriamente a la índole de cuestiones que pueden ser argüidas por el demandado. En estos casos, los tribunales, divisando de lejos una situación jurídica mayor de la que admite una acción de precario, rechazan la acción con la explicación insostenible de que no se trata de precario, porque la cosa originalmente fue entregada al demandado por el demandante.

en los comentarios de jurisprudencia de la Revista de Derecho de la Universidad Adolfo Ibáñez, vols. 2 (2005), pp. 36-50 y 3 (2013), pp. 56-60. 
Así ocurrió, por ejemplo, en Farías con Magner ${ }^{27}$. La demandada de precario se defendió alegando que había sido autorizada por el demandante para usar el inmueble en cuestión que además había sido adquirido durante la convivencia entre ella y el demandante. La Corte Suprema desechó la acción de precario sobre la base de la primera alegación, sosteniendo precisamente que el acuerdo excluye el precario: que una vez producida la separación de la pareja [formada por el demandante y la demandada, de acuerdo con otro de los hechos fijados que enumera la Corte], a mediados del 2000 el actor en forma expresa autorizó a la demandada para continuar la ocupación del inmueble (c.3.d).

A partir de este hecho, la Corte Suprema constata que

En estas condiciones, y conforme a los hechos aludidos en el motivo anterior, resulta evidente que no concurren todos los requisitos que el precario, considera para estimarlo comodato según el inciso $2^{\circ}$ del artículo 2195 del Código Civil, por lo que no se cometió error de derecho al desestimar la demanda de precario (c.4; las comas y su disposición son de la Corte).

Este caso es un buen ejemplo de lo dicho más arriba: la cuestión en realidad eran los derechos que la demandada tenía en la comunidad de hecho que se había formado entre ella y el demandante durante su convivencia. Este asunto debía discutirse en un procedimiento en el que la cuestión de los derechos de cada uno como parte de la comunidad de hecho fundada en la convivencia pudiera ser planteada y solucionada adecuadamente. Como el procedimiento iniciado por una acción de precario no es el adecuado para eso, la Corte se resiste a alterar el statu quo sin que esa cuestión pueda ser discutida, y busca un argumento para rechazar la acción. La razón correcta para rechazarla, de acuerdo con la explicación desarrollada hasta ahora, es que el demandante no ha satisfecho su carga de probar que no tiene deber de tolerar la detentación de la demandada. Pero la Corte no lo hace de este modo: en vez, rechaza la acción con el argumento ininteligible de que no procede porque el demandante "en forma expresa" autorizó a la demandada a ocupar la cosa. Pero que el dueño autorice expresamente a una persona a usar su cosa no crea para el dueño la obligación de tolerar ese uso indefinidamente. De eso se trata el precario, precisamente.

La intuición que lleva a los tribunales a evitar acoger una acción de precario cuando parece haber una controversia jurídica más compleja que la que ese procedimiento puede tolerar es correcta, y muestra lo que ya hemos observado: no basta probar que uno tiene derecho sobre una cosa para probar la ilicitud de la detentación del otro. Pero la manera de articular esta idea no es sostener que la acción de precario tiene como condición que no haya vínculo contractual, porque eso es absurdo. La manera de solucionar este problema es entender que la exigencia de ignorancia o mera tolerancia es positiva y no negativa: corresponde al demandante probar que él no tiene deber de tolerar, porque (tal como ocurre en la acción reivindicatoria, en la publiciana, en la del art. 915 y en

${ }^{27}$ Atria (2005,. "Derechos reales”, pp. 40-41. 
los interdictos posesorios) corresponde al demandante probar la causa de la detentación del demandado.

(b) El demandado detenta con un título que no obliga al actor, porque es un contrato entre otras partes

En este caso el demandado es mero tenedor de un tercero. Como ya hemos explicado, este debería ser un caso claro en que la acción de precario no es procedente, porque el conflicto jurídico real no es entre demandante y precarista sino entre demandante y aquel a cuyo nombre el demandado detenta. El concepto de "ignorancia o mera tolerancia", a mi juicio, debe ser construido para excluir este caso.

Si el demandado es mero tenedor de un tercero el demandante normalmente estará en posición de alegar que, a su respecto, el demandado no tiene título alguno, porque el título que tenga le será inoponible. Si detentar por "ignorancia o mera tolerancia" se entiende negativamente, quiere decir "detentar sin un título que obligue al demandante a tolerar la detentación”, la acción procedería en contra del arrendatario del tercero poseedor, lo que es absurdo. Por consiguiente, detentar por ignorancia o mera tolerancia debe significar algo más radical, y tendrá dos variantes, nuestros casos originales (a) al que detenta en virtud de un título que reconoce el derecho del demandante a requerir la restitución cuando lo desee, y (d) al que detenta sin título alguno (al okupa).

En Olivares y otra con Olguín ${ }^{28}$ la demandada se defendió diciendo ser arrendataria de un tercero (primero por sí y luego como representante de una persona jurídica), que en virtud de una adjudicación (que, sin embargo, no había sido inscrita) tenía derechos sobre el inmueble de cuya restitución se trataba. Esta alegación fue desechada en primera instancia, y la demandada, apelando la sentencia que la condenaba a restituir, insistió en este punto en segunda instancia. La Corte de Apelaciones de La Serena aceptó la alegación de la demandada de ser arrendataria del tercero pero advirtió que la escritura pública de adjudicación de su arrendador "no hace prueba de que tal adjudicatario se hubiese hecho dueño del inmueble por cuanto no se acreditó que estuviese inscrito a su nombre” (c.3). En virtud de esta circunstancia, confirmó la sentencia de primera instancia.

En contra de la decisión de segunda instancia recurrió la demandada de casación en el fondo, alegando que la Corte de apelaciones había decidido que ella detentaba como arrendataria. La Corte Suprema soluciona este problema, al afirmar

que la demandada sea arrendataria de un tercero, que no tiene derecho alguno en el bien raíz, según se estableció en el proceso, no le da título idóneo de mera tenencia, pues para ello era menester que el contrato hubiere sido acordado, evidentemente, con las propietarias del inmueble, lo que en la especie no sucedió; por consiguiente, cualquier acto jurídico celebrado con terceros resulta inoponible para las referidas

${ }^{28}$ Atria (2013), "Derechos reales", en Revista de Dercho de la Universidad Adolfo Ibáñez (vol. 3), pp. 13-73, aquí pp. 56-57. 
dueñas, que nunca han consentido en celebrar contrato alguno con la demandada. Luego, demostrado que las actoras son dueñas del referido inmueble que la demandada lo ocupa sin que medie contrato emanado de aquellas que la habilite para ello y que, por consiguiente, tal ocupación sucede solo por la mera tolerancia de las propietarias, fuerza es concluir, como acertadamente lo hizo el fallo recurrido, que la acción de precario debía ser acogida (c.3).

Lo que la Corte Suprema sostiene no soluciona el problema, aunque lo deja planteado del modo más claro posible: para acoger la acción de precario lo que debía ser calificado no era el título de la demandada, que después de todo había probado que detentaba como arrendataria. Lo decisivo era el derecho de su arrendador. Pero por supuesto, la demandada en esta acción de precario no era legítima contradictoria si de lo que se trataba era de calificar el derecho de su arrendador. Y esto no es un detalle puramente procesal. Aquí radica la relevancia de la distinción entre prueba relativa y absoluta del dominio. El demandante, en una acción de precario, prueba frente al demandado que es dueño. Como el demandando no puede ser poseedor, frente al demandado al actor le será siempre suficiente probar que es poseedor. Pero el hecho de que haya probado ser dueño frente al demandado no quiere decir que pueda probar ser dueño frente al poseedor. En efecto, frente a un poseedor la prueba de la posesión no será suficiente para probar dominio (piénsese en el problema de las dobles inscripciones: ante el demandado de precario la inscripción invocada por el demandante prueba definitivamente su dominio. Pero frente al demandado de reivindicación que invoca su propia inscripción la inscripción del demandante no decide definitivamente las cosas). En Olivares, el hecho de que las demandantes prueben ser dueñas frente a la demandada prueba que tienen mejor derecho que esta, pero no prueba nada respecto de su derecho en relación con el arrendador de la demandada.

La Corte afirma que es indiferente que la demandada haya probado que "es arrendataria de un tercero, que no tiene derecho alguno en el bien raíz”. Pero qué es lo que hace irrelevante esta circunstancia? ¿Es esto irrelevante en virtud de un hecho relativo a la demandada (que detenta en virtud de un contrato de arrendamiento con un tercero) o al tercero (que no tiene derecho sobre la cosa)? El argumento de la Corte descansa en que lo que permite desechar el argumento de la demandada es lo primero ("cualquier acto jurídico celebrado con terceros resulta inoponible para las referidas dueñas”), pero es inequívoco que la razón de verdad es la segunda. Porque si el demandado es un mero tenedor de un tercero, es decir, si detenta la cosa no como dueño, sino en lugar y a nombre de un tercero que tiene la posesión de la cosa, es evidente que el contrato de mera tenencia será, en tanto contrato, inoponible al demandante. Y que si quiere impugnar esa posesión la vía claramente no será la acción de precario contra el arrendatario, sino la acción reivindicatoria contra el arrendador.

Cualquier otra respuesta implica consecuencias inaceptables, de las que podemos mencionar aquí dos. La primera es que el demandante, por una decisión unilateral suya, podría mejorar notoriamente su posición procesal en perjuicio del poseedor. Contra el 
mero tenedor de un tercero, que entonces no es poseedor, el demandante podrá probar su dominio probando su posesión. Pero si el arrendador del demandado es poseedor, la prueba por el demandante de su posesión sería insuficiente frente a él. En un caso como Olivares, se abren aquí varias posibilidades: quizás la sentencia de adjudicación que sería el fundamento del derecho del tercero obligaba a las demandantes, de modo que el tercero podría haber reconvenido ante la reivindicación de las demandantes y haber obtenido una orden para que el juez inscribiera a su nombre; o quizás el tercero tenía una inscripción de la que la demandada no tenía noticia, etc. Lo central es: si el problema es que el dueño no tiene la posesión, la acción debe ser la reivindicatoria contra el poseedor. No puede el demandante mejorar su posición unilateralmente por la vía de demandar no al poseedor, sino al mero tenedor de este.

En segundo lugar, si el dueño puede demandar de precario al mero tenedor sería posible una sucesión de juicios como la siguiente: A, poseedor inscrito, demanda a C, arrendatario de $\mathrm{B}$, y obtiene en el juicio; habiendo obtenido la restitución de la cosa, arrienda a D y ahora B, poseedor inscrito (por ejemplo, por una inscripción de regularización), gana contra D. La posibilidad de esta situación es consecuencia del hecho de que en este caso el conflicto jurídico real es entre A y B, y debe ser solucionado por la acción reivindicatoria. La conclusión es evidente: contra el mero tenedor de un tercero no hay acción de precario, sino el derecho que da al actor el artículo 896.

(c) El demandado detenta con un título que no obliga al actor, porque hay un vínculo ente demandado y actor que por razones formales no satisface las condiciones para justificar la tenencia del demandado

Este es un caso que por razones que serán explicadas necesita separarse de otros casos. Por ello, se trata de un detentador sin título. Por ejemplo, el que detenta todo o parte de un bien inscrito a nombre de otro y que alega como título el hecho de haber comprado al demandante el predio y haberlo recibido en tradición longa manu. En la jurisprudencia de precario, este caso puede tener varias variantes: el contrato puede ser de compraventa o de promesa de compraventa; puede ser por escritura pública o por escritura privada; y puede ser entre el demandante y el demandado o entre los antecesores en la pretensión de dominio de cualquiera de ellos o de ambos. En todos estos casos, con mayor o menor radicalidad, se trata de una situación que se invoca para justificar la detentación del demandado algo que por esa razón no es siquiera en principio suficiente para justificar detentación alguna.

Considérese Santiago con Salazar, un caso perfectamente representativo en el sentido de que no tiene ninguna característica que lo haga especial ${ }^{29}$. El demandado mostró una promesa de compraventa entre él y el antecesor en el dominio del demandante para justificar su detentación de la cosa. El juez de primera instancia acogió la acción; la Corte de Apelaciones rechazó la demanda, sosteniendo que esta no podía prosperar porque se

${ }^{29}$ Atria (2005), “Derechos reales”, pp. 41-43. 
había acreditado el "origen contractual de la tenencia" de la demandada (c.1). La Corte Suprema la acogió, sosteniendo que el contrato invocado "es ajeno al actor y no acredita a su respecto vínculo contractual alguno con la demandada en relación con el bien de su propiedad cuya restitución reclama” (c.3).

El argumento invocado al final por la Corte Suprema hace que el caso sea clasificable bajo (b), en el ítem anterior (el demandado detenta con un título que no obliga al actor, porque es un contrato entre otras partes). Pero hay algo evidentemente mucho más extraño: si se trata de justificar jurídicamente la detentación de una cosa, es evidente que un contrato de promesa de compraventa es impertinente, fuera con el dueño o con un antecesor del dueño. Quien detenta una cosa inmueble con un contrato de promesa de compraventa parece no tener nada de nada de nada: nada, porque la promesa de compraventa no es un contrato traslaticio; de nada, porque no daría derecho a detentar el inmueble aunque fuera traslaticio, mientras no hubiera inscripción; de nada, porque se trata de un contrato que en el mejor de los casos daría a las partes contratantes acciones recíprocas, pero no una acción en contra del sucesor del promitente vendedor, que regularmente compró y recibió la cosa en tradición.

Quizás por eso, uno podría pensar, en este caso la acción de precario fue acogida. Pero nótese que la discusión suponía que el contrato era relevante, a pesar de que no es título traslaticio y que había sido celebrado por el demandado con el antecesor del demandante, no con el demandante mismo: el juez de primera instancia acogió la demanda porque acogió la objeción del documento en el que constaba el contrato, la Corte de Apelaciones rechazó la demanda porque rechazó la objeción, la Corte Suprema acogió la demanda porque el demandante no era parte del contrato (con la implicación obvia de que si hubiera sido parte las cosas habrían sido distintas).

Esta situación no tiene nada de extraño. Lo mismo ocurrió en Zúñiga con Villavicencio, en que el demandado había celebrado un contrato de promesa de compraventa con el antecesor en el dominio de las demandantes, y había pagado el precio, y en el contrato de promesa constaba que por medio de él se había hecho tradición real del inmueble ${ }^{30}$. El juez de la instancia decidió que tanto la promesa de compraventa como la tradición, como el hecho de que el demandado detentara la posesión material (excluido por el art. 994 CC) y que hubiera pagado el precio eran enteramente irrelevantes, por lo que el demandado no tenía nada de nada de nada. De modo no problemático, entonces, la acogió. La Corte de Apelaciones aplicó el mismo criterio, y confirmó. La Corte Suprema, sin embargo, en sentencia de reemplazo revocó la sentencia de primera instancia, porque

En la especie el demandado... celebró con fecha 14 de abril de 1994 una promesa de compra con don José Zúñiga Miranda, autorizado por su cónyuge doña María Teresa Godoy Jorquera, y por su cláusula tercera el promitente vendedor hizo entrega material al referido demandado del inmueble prometido vender, el que don

${ }^{30}$ Atria (2013), “Derechos reales”, pp. 59-60. 
José Zúñiga Miranda (fojas 2) vendió a sus hijos Elena, Claudina y Juan Ignacio Zúñiga en el año 1999, de manera que el antecesor en el dominio de los actores entregó o prestó el inmueble al demandado, por lo que no concurre el requisito [de] que la tenencia de este sea sin previo contrato y por ignorancia o mera tolerancia del dueño (c.2).

El argumento, como se ve, carece enteramente de sentido. La exigencia del artículo 2195 (respecto de precario) no es que el demandado no tenga ningún contrato con alguna persona con relación a la cosa, sino que no esté vinculado con el demandante mediante un contrato que le imponga a él la obligación de tolerar el uso de la cosa. El hecho de que el demandado tenga un contrato con un tercero que es inoponible al dueño actual no puede, obviamente, justificar el rechazo de la acción de precario. Pero, como antes, no basta mostrar que el argumento de la Corte es incorrecto. Es necesario entender también la razón que lleva a la Corte a tener una intuición correcta acerca de cómo decidir, aunque esa intuición no puede fundarse en argumentos coherentes.

La primera pista es que el argumento de la Corte es internamente inconsistente en un sentido que ya se nos ha aparecido: oscila entre la lógica de los derechos personales y los derechos reales. Aplicando la lógica de los derechos personales, identifica los diversos contratos de los que surgieron diversos derechos y obligaciones. Pero luego sujeta esos derechos y obligaciones a un régimen de derechos reales, porque solo desde esta óptica tiene sentido decir que un contrato entre el tenedor actual y el antecesor en el domino del dueño actual le empece en algún sentido a este último: solo si ese contrato entre el tenedor actual y el antecesor en el dominio del demandante fue apto para constituir un derecho real sobre la cosa en favor del primero tiene algún sentido que este invoque el contrato contra el demandante. En algún sentido, los tribunales chilenos están recorriendo un camino que ya ha sido recorrido en múltiples ocasiones (como el surgimiento de la protección posesoria en Roma y el surgimiento del lease como derecho real en el common law), reconociendo efectos reales a actos que legalmente no tienen esos efectos cuando en los hechos han llevado a formas estables y reconocidas (aunque no jurídicamente protegidas) de detentación de las cosas.

Ahora bien, ¿por qué la cuestión ha surgido en las circunstancias en las que ha surgido? Es posible decir todavía algo más aquí. La referencia a la promesa de compraventa, el pago del precio y la entrega material de la cosa, que constituyen habitualmente las razones a las que los tribunales atienden, son tomadas del artículo $19 \mathrm{~N}^{\circ} 1$ del DL 2695 , pertinente a la regularización de la pequeña propiedad raíz. Al final adelantaremos una hipótesis acerca de por qué estas reglas son aplicadas aquí, pero por ahora nos interesa ver cómo operan. Primero, debemos tomar en cuenta la estructura del artículo 19 mencionado. Este contiene las causales en las que se puede basar una oposición a la solicitud de regularización presentada por el poseedor material. El $\mathrm{N}^{\circ} 1$ dispone que se puede oponer el poseedor inscrito del predio de cuya regularización se trata, y a continuación, el inciso $2^{\circ}$ especifica los casos en los que el poseedor inscrito no puede oponerse. Entre esos casos se encuentra el siguiente: 
No podrá invocar esta causal el que solo tenga la calidad de comunero; el que por sí o sus antecesores, haya vendido o prometido vender al peticionario o a aquellos de quien o quienes este derive sus derechos, aunque sea por instrumento privado, el todo o parte del predio y recibido dinero a cuenta del precio, ni tampoco el que invoque una inscripción especial de herencia cuando en la respectiva resolución de posesión efectiva se haya omitido a otros herederos con derecho a ella.

Como antes, hay que observar que en términos jurídicos el peticionario no tiene nada de nada de nada, y el inscrito tiene todo el derecho de su lado: se trata de un contrato no traslaticio de domino, que además es nulo por omisión de solemnidades, que incluso si fuera traslaticio y fuera válido no daría derechos sobre inmuebles porque requeriría de tradición. $\mathrm{Y}$ aunque el peticionario contra el inscrito no tiene nada de nada de nada, la ley reconoce el derecho del peticionario y le niega al inscrito derecho a oponerse. ¿Qué ocurre aquí?

A mi juicio, la mejor interpretación de esta regla es que la ley asume que se trata de un caso en el que ha habido transferencia del domino sobre el inmueble, pero que esa transferencia no es jurídicamente visible. Ella existió, pero no alcanzó a aparecer en el radar del derecho. Como operó bajo el radar del derecho, el derecho no la registró, y por eso el derecho parece estar del lado del poseedor inscrito. Pero en la historia real, en esa que ocurrió bajo el radar del derecho, el que detenta la cosa la detenta lícitamente, porque adquirió el dominio del que aparecía como dueño de ella. Y la legislación de regularización intenta desviarse de los principios de la posesión inscrita para atribuir el derecho a quien sustantivamente corresponda, porque descansa en que la desprotección del adquirente se explica al menos en parte en su falta de acceso al derecho.

El problema, por cierto, es cómo identificar transacciones que son jurídicamente invisibles. Y entonces el artículo 19 N 1 DL 2695 recurre, por así decirlo, a indicios: a marcas que, sobre la línea del radar del derecho, dejó esta transacción que ocurrió bajo esa línea. Las marcas son la promesa de compraventa, la escritura al menos privada, el pago del precio, la entrega de la cosa, etc. Y por cierto, el hecho de que durante los últimos cinco años el peticionario, y no el inscrito, ha poseído pacíficamente la cosa. En esas condiciones, la ley prefiere al poseedor material sobre el poseedor inscrito, a quien le niega derecho a oponerse. Como ya está dicho, los tribunales chilenos están recorriendo una ruta que ha sido transitada ya muchas veces.

\section{LA IRONÍA FINAL}

\section{El régimen especial de regularización y el régimen general del Código Civil}

Al formular lo que luego sería la versión ortodoxa de la "teoría de la posesión inscrita" Humberto Trucco debió enfrentarse a la siguiente objeción:

Se dice: si la inscripción constituye por sí sola posesión, hay que aceptar el absurdo y la consecuencia monstruosa de que, si alguien vende un inmueble ajeno que no está inscrito 
el comprador, por el hecho de inscribir, se coloca en situación de ganar la cosa por la prescripción extraordinaria de treinta años, y puede así expulsar al verdadero dueño y poseedor, que lo era tal vez desde tiempo inmemorial ${ }^{31}$.

La primera respuesta de Trucco (hoy debilitada porque, después de la L 16952, ya no se trata de 30 sino de 10 años) nota que es un caso de "remota ocurrencia", porque es "bien difícil" que el dueño no haya necesitado inscribir para transferir su propiedad, o que esta de un modo u otro no cambie de manos en ese largo tiempo. En cualquiera de esos casos el dueño deberá inscribir, y con eso se hará pública la situación y el dueño podrá reivindicar. Pero esta es solo una defensa dilatoria. La de fondo defiende esta consecuencia aparentemente "monstruosa" y "absurda" incluso en los remotos casos en los que pueda ocurrir. El absurdo y la monstruosidad son solo aparentes, porque el perjuicio para el no inscrito es imputable a su negligencia. Comentando la situación del que adquiere el dominio inscribiendo el predio en este caso, Trucco sostiene:

Pero ¿es cierto que el reconocimiento de un dominio [así ganado] sea atentatorio contra la equidad? En manera alguna. En ello no debe verse sino una sanción legal, un mal a que se ha expuesto el poseedor no inscrito por obra de su propia y personal incuria o desidia, y el que por negligencia o desidia propia se expone a un daño, debe aceptar resignado las sanciones con la que la ley castiga su desidia, por duras que ellas sean, sin pretender una protección tardía que estuvo en sus manos alcanzar al amparo de la ley en cuanto momento durante el largo espacio de treinta años ${ }^{32}$.

Las consecuencias que sufre el que no cumple los requisitos formales para ver protegida su posesión son tan radicales que esa desprotección debe poder ser imputada a la "propia y personal incuria o desidia" del que ha sufrido el perjuicio. Si el dueño, en su negligencia, no se preocupó de inscribir su posesión, y como consecuencia de eso otro logró posesión inscrita sobre el predio, de modo que cuando el dueño quiso ejercer su derecho recién entonces notó que lo había perdido, entonces el dueño solo tiene a él mismo y a su negligencia que culparse.

Es evidente que la plausibilidad de esta justificación depende de dos cosas: la radicalidad de los efectos legales de la falta de inscripción y el grado de familiaridad con las condiciones técnicas de operación del derecho que es necesario mostrar para obtener la protección legal. Y es igualmente evidente que, sin perjuicio de qué es lo que parecía aceptable al legislador en 1855 o a Humberto Trucco en 1910, todo el sentido de la introducción de regímenes de saneamiento de la posesión de inmuebles, desde 1939 (con la L 6382, primera de saneamiento) es que el legislador ha constatado que el supuesto de Trucco es, en las condiciones del siglo XX y tratándose de la pequeña propiedad raíz, insostenible. Que no se puede reprochar negligencia a quien no recurre

\footnotetext{
31 Trucco (1910), “Teoría de la posesión inscrita”, p. 143 (las cursivas son de Trucco).

32 Ibid.
} 
a los mecanismos formales de protección de sus derechos cuando se trata de personas cuyas condiciones económicas o sociales hacen difícil su acceso a la asesoría jurídica. El perjuicio que sufren por el hecho de quedar sin protección jurídica no es reconducible a su desidia, sino a su condición de clase. Dicho de otro modo, el propio legislador ha decidido, en un proceso que solo tendió a agudizarse durante el siglo XX, que debido a la situación de pobreza o marginalidad de los afectados (identificada actualmente por el valor de los predios en cuestión, al tenor de lo dispuesto actualmente por el art. 21 del decreto ley 2695, una regla que proviene del DFL 6/Agricultura/L 16640 de 1968) no es posible imputarles negligencia, y por eso no se justifica negarles la protección del derecho. Ese y no otro es el sentido del hecho de que las reglas acerca de saneamiento protegen a quien se encuentra en condiciones que, conforme al régimen del Código Civil, no tiene nada de nada de nada.

El problema es que, como la dogmática tradicional entiende que el régimen completo del decreto ley 2695 es excepcional ${ }^{33}$, ella concluyó que todas las reglas del decreto ley 2695 se aplican solamente a los procedimientos que ese decreto crea, incluso cuando se trata de reglas substantivas (respecto de quién tiene o no derecho a la cosa).

Y esto deja abierta la posibilidad para casos como Santiago con Salazar o Zúñiga con Villavicencio, en que la acción de precario la ejerce un poseedor inscrito que, si se tratara de un procedimiento de regularización, no tendría siquiera derecho a oponerse. Pero como las partes se encontraron en un juicio de precario, ese mismo poseedor inscrito, en las mismas condiciones, tiene el derecho de su lado y el demandado no tiene, por consiguiente, nada de nada de nada. Nótese la radical diferencia: en las mismas condiciones, el poseedor material tiene toda o ninguna protección frente al poseedor inscrito. Y la cuestión se hace absurda si preguntamos de qué depende que las partes se encuentren en uno u otro procedimiento. La respuesta es: de que el poseedor material haya solicitado la regularización. Pero todo el sentido de la regularización era reconocer el déficit de acceso al derecho del poseedor material. La contradicción no podría ser más flagrante, y deja a los jueces en una situación insostenible: en el juicio de precario, el juez tiene que declarar que el demandado no tiene derecho alguno, a sabiendas de que lo tendría todo si hubiera iniciado el procedimiento de saneamiento a tiempo, y que entonces su negligencia lo condena, aun cuando el legislador ha reconocido una y otra vez que en las circunstancias en las que se encuentra no se le puede reprochar negligencia. No es extraño, entonces, que los tribunales busquen subterfugios para evitar esta conclusión.

\footnotetext{
${ }^{33}$ Porque entiende de nuevo las cosas de modo invertido: entiende que las reglas de saneamiento son casos de lo que se ha llamado "descodificación" (en el sentido de Irti (1992), La Edad de la Descodificación (Barcelona, JM Bosch Editor)), cuando en realidad en ese sentido ellas recodifican lo que el Código Civil mismo, con la posesión inscrita, había descodificado: véase Atria (2011): "La tierra para el que la trabaja", en Figueroa, Barros, et al. (eds.), Estudios de Derecho Civil, VIII (Santiago, LegalPublishing).
} 


\section{BIBLIOGRAFÍA}

Álvarez, H. (1928). La Inscripción no es Requisito, Garantía ni Prueba de la Posesión de los Bienes Raíces (Santiago, Imprenta y librería "Artes y Letras").

Atria, F. (2005). “Derechos reales”, en Revista de Dercho de la Universidad Adolfo Ibáñez (vol. 2), pp. 29-97.

Atria, F. (2011). "La tierra para el que la trabaja”, en G. Figueroa et al. (eds.): Estudios de Derecho Civil, VIII (SAntiago, LegalPublishing).

Atria, F. (2013). "Derechos reales”, en Revista de Dercho de la Universidad Adolfo Ibáñez (vol. 3), pp. 13-73.

Atria, F. (2017). "Acciones reales de proteción del dominio y de mejor derecho (revindicatoria, publiciana, del art. 915)", en Ius et Praxis, volumen $23 \mathrm{~N}^{\circ} 2$ (en prensa).

BARCiA, R. (2017). "La concurrencia de acciones reales a la luz de la jurisprudencia de la Corte Suprema en torno a la posesión material", en Revista de Derecho (Coquimbo), volumen 24 $\mathrm{N}^{\circ} 1$ (en prensa).

Domínguez Águila, R. (2005). "Instituciones jurisprudenciales en el Código Civil chileno”, en M.D. Martinic y M. Tapia (eds.): Sesquicentenario del Código Civil de Andrés Bello (Santiago, LexisNexis).

Domínguez Hidalgo, C. y R. Domínguez Benavente (1991). "Lo que la jurisprudencia se llevó”, en Revista de Derecho de la Universidad de Concepción (vol. 189), pp. 95-110.

Halabí Riffo, F. M. y C. A. Saffirio Suárez (1996). La Acción de Precario ante la Doctrina y la Jurisprudencia (Santiago, ConoSur).

IRTI, N. (1992). La Edad de la Descodificación (Barcelona, JM Bosch Editor).

Larroucau, J. (2014). "La prueba completa del dominio en la acción reivindicatoria", en Estudios de derecho Civil IX (Santiago, LegalPublishing).

Larroucau, J. y I. Rostión (2015). "Del juicio de precario”, en R. Barcia (ed.) Derechos Reales (Santiago, Legal Publihsing).

Lathrop Gómez, F. (2011). "Procedencia de la acción meramente declarativa del dominio en el derecho chileno”, en Ius et Praxis (vol. 17), pp. 3-24.

López, J. (2004). “Obligaciones y contratos”, en Revista de Derecho de la Universidad Adolfo Ibáñez (vol. 1), pp. 57-84.

Moreno, M. (1951). El Precario (Barcelona, BOSCH).

PÉrez, M. F. (2014). "La protección del dueño ante quien retiene indebidamente un bien: análisis jurisprudencial del artículo 915 del código de bello", en Revista de derecho (Coquimbo) (vol. 21, número 1), pp. 387-421.

Ramos Pazos, R. (1986). "El precario", en Revista de derecho de la Universidad de Concepción (vol. 180), pp. 7-19.

Rostión, I. (2013). El Precario en la Jurisprudencia Chilena (Santiago, LegalPublishing).

Selman, A. (2011). "Artículo 915 del Código Civil: una solución jurisprudencial a la limitación de las acciones tradicionales", en Ius et Praxis (vol. 17), pp. 57-80.

Trucco, H. (1910). “Teoría de la posesión inscrita dentro del Código Civil chileno”, en Revista de Derecho y Jurisprudencia (vol. 6), pp. 131-155.

Vergara, S. (1991). El Comodato Precario y el Simple Precario ante el Derecho y la Jurisprudencia (Santiago, Conosur).

\section{JURISPRUDENCIA CITADA}

Castro con Reyes, sentencia de la Corte Suprema, dictada el 2 de abril de 2003, en causa rol 1337-2002. 
Comunidad con Tapia, sentencia de la Corte Suprema, dictada el 8 de septiembre de 2003, en causa rol 5061-2002.

FARías con Magner, sentencia de la Corte Suprema, dictada el 27 de mayo de 2004, en causa rol 2461-2003.

Olivares y otra con Olguín, sentencia de la Corte Suprema, dictada el 20 de marzo de 2003, en causa rol 4477-2003.

SANTIAGo con Salazar, sentencia de la Corte Suprema, dictada el 18 de mayo de 2004, en causa rol 4732-2002.

ZÚÑIGA con Villavicencio, sentencia del a Corte Suprema, dictada el 8 de marzo de 2005, en causa rol 4164-2003. 